\title{
ISLAM, STATE AND SECULARISM; ANALYSIS ON THE SUBSTANTIVE POLITICAL PARADIGM IN INDONESIA
}

\author{
Mohamad Latief ${ }^{1}$, Mifedwil Jandra Janan ${ }^{2 *}$ \\ ${ }^{1}$ Lecturer at Darussalam University, Gontor \\ ${ }^{2}$ LPPM UIN Sunan Kalijaga \\ *Corresponding author:jandraj6@gmail.com
}

\begin{abstract}
Article history
Received:14/09/2015

Received in revised form:14/09/2015

Accepted: 18/10/2015

Abstract

This research aims at analyzing political secularism in Indonesia and most specifically dealing with the recurrent polemic upon the relationship between Islam and State. The research initially seeks to describe the political situation of the country where the formalistic and substantives debate, especially on their distinctive approach to stipulate the proper role of religion on the country's politic, could be witnessed. The description, however, will deal more on the latter political paradigm which is increasingly grasping an impressive preference from numbers of political individuals and institutions particularly when they come to discuss Islamic tenets and their application within the context of a pluralistic society like Indonesia. Using normative and socio-historical approaches, the paper argues that this political preference, despite its convincing successes in Islamizing the country's politic, still suffers from numbers of defects that finally raise our apprehension. These defects summarily provide proofs to the questioned commitment of the substantive to the Islamic political values as a whole; the one which reveals an agreed separation of the state and religion; the one of secularism.
\end{abstract}

Keywords; Formalistic, Substantive, Secularism, Partai Kebangkitan Bangsa, Partai Amanat Nasional. 


\subsection{INTRODUCTION}

The wide-spread phenomenon of modernity, that transcends territorial boundaries of all states, implies the spreading of the Western religious and philosophical paradigm it contains. As one of the key elements of the Western modernity, secularism becomes of a common thing occupying the minds of all people. Despite its universalistic nature, responds given to secularism are quite different from one country to the others. In this context, the Muslim populous country of Indonesia requires special attention. The processes of secularization therein, however debatable, appears in the transformation of the formalistic political paradigm of the Muslim society into the substantive one. This transformation discloses the lowering or the decrease of commitment by the substantive toward a single religion that is Islam and the growing tolerance toward pluralism and universal principles that stand above all religions. This transformation is actually a result of intellectual renewal that aimed at defining a more harmonious relationship between the state and religion in the country. There are no brutal or radical actions required for this transformation to arise. The process is then smooth and non-aggressive.

This research seeks to analyze secularism, its emergence and development, with special emphasis on the relationship between Islam and State in Indonesia. In this regard, the prevailing substantive political paradigm will receive most attention since it is relatively associated with the principles of separating politics from religion posed by secularism.

\subsection{ISLAM AND STATE IN INDONESIA}

Discussion on the relationship between Islam and state is one of the most demanding discourses and, in fact, an indivisible element should we analyze the history and development of the Indonesian politic. The mode of relationship between Islam and state in Indonesia is commonly coloured with mutual antagonism and distrust (Bahtiar Effendy, 2003; 13). On a discursive level, this situation is due to an intellectual conflict that attempts to conceive of necessity in defining the limits of religion and state (Budhy Munawar Rachman, 2010; 76).

During the initial phase of the intellectual development of the country, this conflict was manifested overtly on a debate between the Islamist vis-à-vis secular nationalist groups with regard to the ideology (weltanschauung) of the state (Saripuddin H.A, 2000; xi-xii). While the former, represented by Agus Salim and Mohammad Natsir, supported Islam as the state's ideology, the latter, represented by Soekarno, opted Pancasila as its ideology (M. Dien Syamsuddin, 2002; 2229). In this initial debate, the former was, in short, forced to compromise with their demand and agree with the latter's, decline from insisting to adopt the Jakarta Charter (Saifuddin Anshari, 1979) and finally scale down to accept Pancasila as the ideology of the state (Budhy Munawar Rachman, 2010; 91).

Despite this defeat, in the next stages the Islamist never stops struggling to achieve their political vision. Through formal and structural approach, Masyumi, a contestant from among Islamic political parties which gained majority vote in general elections year 1950 up to 1959, was not hesitate to insert its political program affirming the making of Islam as the ideology of the state and the viable political form of the government. Meanwhile, the aggressive and frontal approach was apparent in numbers of region-based military movements that posed a direct threat to the country like that of Darul-Islam, Revolutionary Government of the Republic of Indonesia (PRRI), Perjuangan Semesta Alam (Permesta) and so on (Herbert Feith \& Daniel S. Lev, 1963; John D. Legge, 1961; C. Van Dijk, 1981; Barbara S. Harvey, 1977).

But this approach was short-lived in that its aggressive and formalistic character was seen negative by some other and thus oppressed so severely by the ruling government. The issuance of presidential Decree (Dekrit Presiden) by Soekarno in 1959, the arrest, if not killing, and imprisonment of those involved in any military movement, reluctance shown by the ruling government of the Old Order to rehabilitate Masyumi leaders etc, are of evidences that owe a complete repudiation of the government over the formalistic approach. This rejection was apparent not only during the old regime but also new one (New Order) under the dictatorial leadership of 
Soeharto. His political attitude toward Islam was not so much different from that of his predecessor and in fact inherited similar perspective that holds Islam negatively and sees it like an overt enemy loaded with all potentials to threaten his leadership. Islam had been once considered his second enemy after communism and cursed as a "right extreme" (Budhy Munawar Rachman, 91-92; Bahtiar Effendi, 2000; 197-8).

\subsection{THE SUBSTANTIVE POLITICAL PARADIGM}

The aforementioned description is actually trying to assert that, however debatable, the developmental political process in Indonesia, stretching from the beginning of its inception up to the New Order era, suffers from complexity of rifts and trouble. This is partly due to the undefined synthesis between state and religion. The most crucial fact is perhaps pointed at the time when the Muslim society was largely victimized for ideological reasons and thus marginalized from national political processes (M. Syafi'I Anwar, 13; B.J. Boland, 1971). It is from this political marginalization that lends a real credence for Mohammad Natsir of Masyumi to accuse the ruling government as serving the Muslim society like a Kucing Kurap (Mohammad Hasan Kamal, 1982; 121). Considering this, a new generation of Muslim intellectuals, rising particularly during 1970s, initiated to develop a new political formulation so as to generate a harmonious relationship between Islam and state in Indonesia. These Muslim intellectuals attempted to formulate an Islamic political paradigm that is more adaptable or adjustable with the socio-political and cultural condition of the plural Indonesia. It is of a political paradigm that is more open-minded, inclusive and tolerant with heterogeneity of the country. And most importantly, it is of a political paradigm that concerns more on the substance, instead of symbol, of the Islamic religion (Din Syamsuddin, 2002, 57-65; Marzuki Wahid and Rumadi, 2001, 22-33).

The emergence of these substantive intellectuals, sometimes associated with cultural Islam (Islam kultural) provides an alternative to the displayed array of political thought in Indonesia offering a social transformation of the society supposedly attained through introducing a more tolerant attitude of Islam that is not too much ideological and dogmatic like entertained obviously during the old era (Bahtiar, 191). This will combine three main agenda; first, re-examination of the theological or philosophical underpinnings of political Islam, second, redefinition of the political objectives of Islam and third, reassessment of the ways by which those political ideals can be effectively realized; all of which call for a theological renewal inclusive of a need for desacralization, reactualization and indigenization, political or bureaucratic reform and social transformation (Bahtiar Effendy, Islam and the State, 66-90). Among the scholars who belong to this group are Nurcholish Madjid, Munawir Sadzali, Abdurrahman Wahid, Harun Nasution etc.

The issue of secularization or desacralization, advocated by Nurcholish Madjid, is comparatively worth of mentioning. The severe condition of the Muslim society, despite their numerical strength, and their lost in every political competition of the country was, according to him, due to number of reasons that embedded so strongly on their mindset and especially the theological paradigm. This theological paradigm, he maintains, grows out of the Islamic tradition and was inherited by the new from the old generations. He, therefore, insists of a necessity that calls for a theological renewal by a withdrawal and freeing one's self from the tradition and, simultaneously, finding out the future-oriented and substitute values (M. Kamal Hassan,286.) The Muslim society's backwardness was, explains he, a result of loss of psychological striking force comprehensively derived from the Islamic religion (Nurcholish Madjid, 1970; 1-12). This manifests in their unwitting inability to differentiate the transcendental from the temporal values of the religion. This intricacy is then getting deteriorated when most of them conceive of everything as purely transcendental, holy and sacred where a critical observation is never permitted. This, consequently, leads to the blending of Islam and tradition, sacred and profane, transcendental and temporal. The hierarchy of values is then constructed reversely; the transcendental is conceived as temporal and vice versa. This, in return, explains the main cause for their inability to actively respond the development of the modern world (M. Kamal Hassan, 286). 
This renewal of the theological understanding advocated by the substantive or cultural Islam, in short, brings about numbers of outcomes. Within the internal circle of the Muslim society, this renewal offers a new political paradigm that is prone to concern more on the substantial values of Islam; the ones which are hiding behind every symbol. This substantive paradigm suggests that Islam provides only of moral values which serve as the basic and general guidelines for human life, and though holistic, it never regulates every aspect of life and especially concerning the political one. There is no, it maintains, clear indication that Islam has a profound interest in regulating issues pertinent to the affairs of the state. The idea of an Islamic state or Islamic ideology, interestingly, is only a form of apologetic tendency that represents an apologia to the dominant position of the western ideologies such as liberal-democracy, socialism, capitalism and to the legalistic tendencies of some Muslim in their understanding of Islamic religious tenets (Nurcholish Madjid, 1991\& 1984, 17-8; Abdurrahman Wahid, 1986; Munawwir Syadzali, 1990; Bahtiar Effendy, 105-6). This understanding further throws light for the substantive's support for the maintaining of Pancasila as the ideology of the state, the Republic of Indonesia as the form of the government, advocating democracy and pluralism, condemning the formalization of Islam in the political context of the country, denying the return and application of the Jakarta Charter, refuting the foundation of an Islamic state and Shariah Islam and the likes.

\subsection{THE POLITICAL SECULARISM}

The substantive political paradigm is in fact a result of political renewal and reformulation, proposed by the 1970s' Muslim intellectuals, to fill the gap within the relationship of the state and religion and find out a more appropriate place for Islam within politic of the pluralistic country of Indonesia. But there rises a problem. Process of a relatively separation of the state from the religion seems to implicitly appear. A high respect and unlimited appreciation toward pluralism and tolerance would amount only of a subsequent denial of being committed with a single worldview. A substantive-minded citizen believes that within a pluralistic society, there are ideas, perceptions, worldviews that are different, and even more conflicting, of each other. Being confronted with this situation, he is then forced not to view the world selfishly from his own perspective. This is arguable since what he understands "good" may not be "good" according to the others. The viewing of the world from a single perspective thus leads to conflict and this, in turn, denies the possibility of harmonious relationship among all citizens. The conception of "good" is thus defined not by a single religion, but a mutual agreement among various religions. The establishment of a harmonious relationship among the citizens hence is not based upon principles drawn selfishly from a single religion, rather a collective and mutual understanding of all religions. The process of separation of the state from the religion thus happens in this way; high appreciation toward pluralism and reluctance to submit one's self toward a single religion or worldview (Harvey Cox, $1965 ; 3)$.

In the Indonesian political context, the partial submission of the substantive toward universal values i.e. equality, freedom, justice etc, is one of those proofs implying its reluctance to believe in one religion. The definition of these values is no more given by Islam but nationalism instead. This obviously explains why the substantive rejects the implementation of shariah, the adoption of the Jakarta Charter, Islamic ideology etc. It is from this short argumentation that this partiality toward nationalism denotes the decrease, if not disappearance, of commitment by the substantive toward Islam (Peter L. Berger, 1969\& 1967; 107-8). In line with this direction, Smith's polity-transvaluation secularization concedes that secularization will apparently take place should there be a shift of paradigm among the society illustrating their prompted belief and conviction upon nationalism, pluralism, equality etc at the expense of Islam (Donald Eugene Smith, 1970; 115). The transformation of old political paradigm, which insists upon a legalistic and formalistic nature of the Islamization, into new one, which defends a rather tolerant and inclusive substantive political approach, reveals this process of secularization (Donald Eugene Smith, 1970; 85-123).

\subsection{PARTAI KEBANGKITAN BANGSA AND PARTAI AMANAT NASIONAL}


In the current political situation, the substantive political paradigm is best personified by Partai Kebangkitan Bangsa (PKB) and Partai Amanat Nasional (PAN). Being established during the reformasi period, both parties share lofty ideals in improving the life of all the Indonesians and supporting the contriving of an accountable and democratic governance (AD/ART PKB, 2008 \& Platform and AD/ART PAN, 2010).

By emphasizing the substantive nature of Islam, PKB and PAN are convinced that formalization of Islam in the political realm of the country is a clear evidence of sectarianism. And there is no place for sectarianism nor religious formalism in Indonesia because of its pluralistic nature. Islam is therefore to be presented in its inclusive appearance thus acceptable by all without fear of any discrimination. Within the contemporary political context of the country, both believe, Muslim political activists should have to draw their attention and accentuation more to the substantive political paradigm than the formalist one. This is explicitly expressed by Abdul Malik Haramain;

"Formalization of Islam is not significant.... PKB agrees with Bung Karno in affirming that Islam is different from ideology. But we have to account for ideologies that reflect the very values of Islam. Be this the case, Islam becomes a spirit and morale for Pancasila. PKB/ Nahdlatul Ulama accordingly concede that Islam be interpreted from its substantive aspect and need not be manifested in its formal construction like Islamic state, Islamic school, Islamic Bank (Shariah) and so on".

(Abdul Malik Haramain, 2013)

In line with this notion, Achmad Rubaie stated;

"PAN does not strive for the formalization of Islam but its substance instead. Upon this preference, PAN wishes to behold how the non-Muslim pleasantly practice the Islamic teachings; the one that might be kind of a magnet for them".

(Achmad Rubaie, 2013).

As democratic parties, both PKB and PAN are champions of the principle of equality. This is realized by becoming plural and open political parties. All Indonesian citizens are considered equal and have equal rights to channel their political aspirations through PKB or PAN. By doing so, PKB and PAN have successfully exposed their inclusive political image not to exclusively take side to any group but are conversely able to lay down all the groups into a similar level of political rights.

Parallel with this, there is another issue that requires further discussion. That is the position of Islam in the party platform. PKB and PAN appears exactly consistent with their commitment to the principle of equality. Both parties are neutral and do not show excessive partiality towards Islam. At least, this fact can be analyzed through reviewing the statutes of the party that does not explicitly mention Islam or certain other religions. It does not state clearly where the position of Islam in the party framework. And if there are found some statements that are implicitly associated with Islam, it does not necessarily imply the party's alignments or siding exclusively toward Islam. Concerning this, the basis and principle of PKB make a mention that;

"The party is based on God, just and civilized humanity, the unity of Indonesia........ the party's principles of struggle is devotion to Allah Subhanahuwa Ta'ala, upholding truth and honesty, upholding justice, safeguarding the unity, brotherhood and unity that grows in line with the Islamic values of Ahlussunnah Wal-Jama'ah."

(AD/ARTPKB, 2008)

This is the case with PAN. The party's statute does not mention explicitly the position of Islam. Principles and vision of the party, for example, mention that; 
"The principle of the National Mandate Party is a political morality based on religion that brings mercy to all in the universe."

(Platform and AD/ART PAN, 2010)

"The realization of PAN as the leading political parties in building up just and prosperous civil society, good and clean government in the democratic and sovereign state of Indonesia, blessed by Allah Subhanahu Wa-Ta'ala, the Almighty."

(Platform and AD/ART PAN, 2010)

According to Islamic perspective, belief in the One God means tawheed (monotheism), which has an important role in animating the following precepts of Pancasila. It is a concept of God that recognizes Allah as the only God to be believed and worshiped. This first principle of Pancasila also refers to a concept of Islamic faith which declares that there is no God but Allah and Muhammad is the messenger of Allah (Adian Husaini, 2009; 131-178).

However, this signification is not the official view of PKB and PAN. Both parties have their own cognition of the principle without implicating the very Islamic interpretation of tawheed. Belief in the One God has accordingly diverse meanings. It does not necessarily mean tawheed, as believed by Muslims, but can also be interpreted as the Godhead or deity in its broader context of interpretations. Every citizen has the right to give his interpretation on the principle of belief in the One God, as well as the other principles of Pancasila. All forms of interpretations are justifiably correct and therefore placed equally in the party's platform. Despite, every form of interpretation of a private and personal in nature and should not therefore be exhorted to be the only meaning promoted officially by PKB and PAN. Thus, the desired interpretation should be open, thorough and inclusive so as to encompass all the meanings exclusively given by each religion that every member of PKB and PAN embrace (Eko Hendro Purnomo, 2014; M.Najib, 2013). Based on this stance, implying religiosity to belief in the One God is more favourable than bearing witness that there is no God but Allah and that Muhammad is the messenger of Allah (tawheed). Conclusively, belief in the One means mere religiosity.

In a much more practical sense of illustration, separation of politics from Islam is adequately manifested in PKB and PAN's response toward issue of Shiah and Ahmadiah. Both adduced reluctance as to address the issue. PKB and PAN show certain attitude of neutrality and are careful as to show their impartial standing towards the opposing groups. This attitude is carried out for the two believe that the state should not interfere nor judge actions that belong to private affairs.

The state should stop at the front door of the mosque or the church door and do not need to go into it. By doing so, the state is acting as a medium, intermediary or a convenience-guarantor that safeguards the harmonious life of the adherents as the whole. Andi Muawiyah Ramli, for example, asserted that:

"The truth according to the PKB is not single (solitary). It belongs to the property of each person or group. PKB defends Shiite-Ahmadiah and I regret very much the attitude of some Muslims who do not want to live side by side with the Shiite-Ahmadiah follower... The state hence needs to play a role as a medium or vehicle to hold and convey the aspirations of each group."

(Andi Muawiyah Ramli, 2013; Similar notion also shared by Abdul Malik Haramain, Sandy Nayoan and Helmy Faishal Zaini; 2013)

Sharing the similar view, PAN upholds that the state maintain peace and harmony between the warring groups and refrain from interfering their very belief or faith. According to Ahmad Rubaie;

"Within the context of teachings (doctrine), we must explore the religion. The state cannot intervene therein. But when it is put in the context of polity, in that the Ahmadiah's existence 
causes tension in the society, then the state shall have to meddle. This is so because the task of the state is to protect all citizens...So the state cannot enter in to the territory of doctrine (teachings).The state is only a facilitator. The doctrine belongs to the right and affairs of each adherent".

(Achmad Rubaie, 2013)

This standpoint is expressly stated by M. Najib. According to him;

"The state should not be indifferent to the problems faced by its citizen, whoever he is and no matter the measure of resolution like those confronting the other people of different places. Resolution or settlement should not be differentiated. As far as Shiite is concerned, the rift should not be dealt with hatred, because such an approach has failed in many countries. In most cases, the majority demands its suppression. This could not be tolerated. The most important thing is therefore community awareness and their standard of education. The fools is hard to act or think wisely. So we need to assure the religious leaders' understanding (upon this), because not all the leaders understand the religion ".

(M. Najib, 2013)

It is construed therefore that, in Shiite and Ahmadiah issue, PKB and PAN choose solely to play an intermediary role or arbitrator. Both parties do not directly and firmly declare, for example, that Ahmadiah is not part of Islam. PKB and PAN opt not to proclaim that Ahmadiah deviates Islam, goes astray and is accordingly infidel. PKB and PAN remain neutral, impartial and inclusive. The writer is therefore of the opinion that this neutrality, added with absence of undertaking specific political measures like ordered by Islam, then secularism, especially on the basis of legitimacy, has profoundly been in existence and prevailing.

\subsection{Conclusion}

The paper shows that the political secularism is apparent in the Indonesian political landscape. Through exploring the relationship between Islam and state, the political secularism is perceptible in the substantive political paradigm. In contrast with the formalistic, the substantive contends that the Muslim concern more on the substance, instead of symbols, of the Islamic religion. It suggests that Islam provides only general values and guidelines, like justice, equality, freedom etc, and never regulates every particular aspect of human's life. On the one hand, this political paradigm has been seen tolerant, inclusive and cordial with plurality, but on the other, it evokes a socio-political and ethical relationship of the society based on universalistic norms at the expense of Islam. In the current political scenario, this political paradigm is evident in the case of PKB and PAN. Despite their historical and cultural closeness with Nahdlatul Ulama and Muhammadiyah, PKB and PAN stipulate their political platform as accorded to the universalistic principle of nationalism and democracy. As a result, no single religion, most specifically Islam, occupies the highest part of the parties' political hierarchy nor is specified as the source of their political legitimacy.

\section{References}

Abdul Malik Haramain (member of the Indonesian Parliament from PKB faction on period 20092014) in an interview with the writer on 23th September 2013.

Achmad Rubaie (PAN faction member in the Indonesian Parliament for period 2009- 2014) in an interview with the writer on 23th September 2013.

Andi Muawiyah Ramli (member of the PKB faction in the Indonesia parliament period 2009-2014) during an interview with the writer in September $24^{\text {th }} 2013$.

Anggaran Dasar dan Anggaran Rumah Tangga PKB, Hasil Muktamar Luar Biasa PKB, di Ancol (Jakarta 2008).

Anshari, Saifuddin, the Jakarta Charter 1945; the Struggle for an Islamic Constitution in Indonesia (Kuala Lumpur: Muslim Youth Movement of Malaysia [ABIM], 1979). 
Anwar, M. Syafi'I, Pemikiran dan Aksi Islam Indonesia; Sebuah Kajian Politik tentang Cendekiawan Muslim Orde Baru (Jakarta; Paramadina, 1995).

Berger, Peter L., the Social Reality of Religion (London: Faber and Faber, 1969). It is published in the USA under the title The Sacred Canopy, 1967.

Boland, B.J., the Struggle of Islam in Modern Indonesia (the Hague: Martinus Nijhoff, 1971).

Cox, Harvey, the Secular City; Secularization and Urbanization in Theological Perspective (New York: The Macmillan Company, 1965).

Dijk, C. Van, Rebellion under the Banner of Islam; The Darul Islam in Indonesia, (the Hague: Martinus Nithoff, 1981).

Effendy, Bahtiar, (Re)politisasi Islam; Pernahkan Islam Berhenti Berpolitik? (Jakarta: Penerbit Mizan, 2000).

Effendy, Bahtiar, Islam and the State in Indonesia (Singapore: Institute of Southeast Asian Studies, 2003).

Eko Hendro Purnomo, "PAN; Kami partai terbuka tak Cuma satu agama", http://nasional.kompas.com/read/2014/04/04/0647507/PAN.Kami.Partai.Terbuka.Tak.Cu ma.Satu.Agama, accessed by Jun $18^{\text {th }} 2014$.

Feith, Herbert dan Daniel S. Lev, The End of Indonesia Rebellion, Pacific Affair 36, no. I (Spring 1963).

Harvey, Barbara S., Permesta; Half a Rebellion (Ithaca: Southeast Asia Program, Cornell University, 1977).

Hassan, Muhammad Kamal, Muslim Intellectual Responses to "New Order" Modernization in Indonesia (Kuala Lumpur: Dewan Bahasa dan Pustaka, Kementerian Pelajar Malaysia, 1982).

Helmy Faishal Zaini (the Indonesian parliament from PKB faction for period 2009-2014, in an interview with the writer on October $3^{\text {rd }} 2013$.

Husaini, Adian, Pancasila Bukan Untuk Menindas Hak Konstitusionil Umat Islam; Kesalahpahaman dan Penyalahpahaman terhadap Pancasila 1945-2009 (Jakarta: Gema Insani, 2009).

M. Najib (member of the Indonesian parliament from the faction of PAN period 2009- 2014, in an interview with the writer on September $24^{\text {th }} 2013$.

Madjid, Nurcholish, Agama dan Negara dalam Islam; Sebuah Telaah atas Fiqh Siyasi Sunni, Paper delivered in 1991 at Paramadina Religious Study Club, Jakarta.

Madjid, Nurcholish, Islam Punya Konsep Kenegaraan? Tempo, December 29, 1984.

Madjid, Nurcholish,"Keharusan Pembaharuan Pemikiran Islam dan Masalah Integrasi Ummat,"dalam Pembaharuan Pemikiran Islam, ed. Nurcholish Madjid et al, (Jakarta; Islamic Research Centre, 1970).

Platform dan Anggaran Dasar Anggaran Rumah Tangga Partai Amanat Nasional, Hasil Kongres III PAN di Batam, 8-10 Januari 2010

Rachman, Budhy Munawar, Argumentasi Islam Untuk Sekularisme; Islam Progresif dan Perkembangan Diskursusnya (Jakarta: PT Gramedia Widiasarana Indonesia, 2010).

Sandy Nayoan in an interview on $24^{\text {th }}$ September.

Saripuddin H.A (ed.), Negara Sekuler; Sebuah Polemik (Jakarta; Puri Berdikari Bangsa, 2000).

Smith, Donald Eugene, Religion and Political Development (Boston, USA: Little, Brown and Company, 1970). 
Mohamad Latief \& Janan / UMRAN - International Journal of Islamic and Civilizational Studies. vol.3, no.3-1 (2016), 28-36

Syadzali, Munawwir, Islam dan Tata Negara; Ajaran, Sejarah dan Pemikiran, Jakarta; UI Press, 1990.

Syamsuddin, M. Dien, "Beberapa Catatan Problematika Politik Islam di Indonesia,"in Problematika Politik Islam di Indonesia, ed. Abuddin Nata, (Jakarta: Grasindo, 2002).

Syamsuddin, M. Din, Etika Agama dalam Membangun Masyarakat Madani (Jakarta: PT Logos Wacana Ilmu, Juni 2002).

Wahid, Abdurrahman, Islam Tak Punya Konsep Baku Mengenai Negara, Kompas, November 24, 1986.

Wahid, Marzuki and Rumadi, Fiqh Madzhab Negara; Kritik Atas Politik Hukum di Indonesia (Jogjakarta: LKiS, February, 2001). 